\title{
Pentingnya Melatih Problem Solving pada Anak Usia Dini melalui Bermain
}

\author{
Putri Nadila ${ }^{1}$, \\ ${ }^{1,2}$ Pendidikan Anak Usia Dini, Universitas Negeri Padang \\ * e-mail: ${ }^{1}$ putrinadila1997@gmail.com,
}

\begin{abstract}
Penelitian ini merupakan studi literatur yang bertujuan untuk mengetahui pentingnya melatih problem solving pada anak usia dini melalui bermain, penelitian ini menggunakan berbagai sumber tertulis seperti artikel, jurnal, dan dokumen yang relevan dengan yang akan di teliti dalam penelitian ini. Hasil yang didapatkan dalam penelitian ini yaitu bahwa pengenalan problem solving kepada anak sejak dini sangat penting dilakukan harna dapat membuat anak berpikir secara kritis, sistematis dan membiasakan anak mencari suaru jawaban dari permasalahan serta menarik kesimpulan dengan tidak tergesa-gesa. Permainan yang dapat dilakukan dalam menanamkan jiwa prolem solving pada anank yaitu dengan permainan puzzle, muse, bongkar pasang dan sebagainya.
\end{abstract}

Keywords: problem solving, anak usia dini

\section{PENDAHULUAN}

Anak usia dini merupakan anak yang berada pada usia 0-8 tahun yang memiliki perkembangan serta pertumbuhan yang sangat pesat. Pada masa ini sering kali disebut masa emas atau golden age. Oleh karena itu, orang tua, gurus erta lingkungan sekitar perlu memberikan simulasi-simulasi yang tepat untuk mengembangkan segala aspek yang ada pada diri anak salah satunya yaitu dengan memberikan pendidikan. Pendidikan anak usai dini merupakan suatu cara untuk mengembangkan segala aspek yang ada pada diri anak secara menyeluruh. Undang-undang nomor 20 tahun 2003 pasal 1 butir 4 mengemukakan bahwa pendidikan anak usia dini merupakan suatu pembinaan yang ditujukan untuk anak usia 0-6 tahun untuk memberikan rangsangan untuk membantu pertumbuhans erta perkembangannya baik secara jasmani maunpun rohani agar anak memiliki kesiapan untuk kejenjang pendidikan selanjutnya.

Agar perkembangan serta pertumbuhan anak dapat berkembang dengan optimal maka perlu pemberian simulasi yang tepat untuk mengembangkan segala aspek yang ada [ada diri anak. Aspek perkembangan yang harus dikembangkan berupa aspek nilai dan moral, bahasa, sosial-emosional, serta seni. Segala aspek saling berkaitan dan sangat penting untuk dikembangkan seperti pada aspek kognitif dimana pada aspek ini anak belajar dalam memecahkan masalah serta menciptakan sebuah karya. Gardner (dalam susanto, 2011) mengemukakan kognitif merupakan kemampuan individu dalam memecahkan atau menyeselaikan sebuah masalah. Sejalan dengan itu K.Pendidikan \& kebudayaan (2015) mengemukakan bahwa kognitif merupakan pemikiran yang dapat digunakan untuk mengatasi suatu permasalahan dengan cepat dan tepat.

Piaget (2007) menyimpulkan perkembangan kognitif merupakan sebuah istilah dari segala model pemahaman baik berupa persepsi, imajinasi, mengolah makna, penilaian serta penalaran terhadap suatu peristiwa. Pembelajaran kogniti fterbaik atas 2 aktivitas yaitu memngingat dan berpikir. Salah satu masalah yang dapat membuat anak berpikir yaitu problem solving dimana dengan 
problem solving diharapkan anak dapat memiliki tantangan dalam belajar. Sejalan dengan itu burner (dalam Riyanto,2010) mengemukakan pembelajaran dengan menerapkan pemberian masalah dapat membaut anak terpacu dalam mencari konsep. Penerapan metode problem solving perlu dikembangkan sejak dini karena dengan pemecahan masalah dapat membuat anak mengembangkan kemampuan kognitif anak atau dapat dikatakan dengan membiasakan Problem solving kepada anak sejak dini dapat melatih anak dalam memecahkan masalah dan mencari jalan keluar. Metode problem solving adalah metode yang berpusat kepada anak seperti yang dikemukakan oleh abu ahmadi (dalam utami) bahwa problem solving memerlukan kesanggupan dalam berpikir, oleh karena itu maka sekolah sudah sewajarnya menerapkan metode problem solving dalam memberikan materi pelajaran agar anak terbiasa berpikir kritis dan memecahkan masalah. Sejalan dengan itu gagne (dalam mulyasa,2006) mengemukakan bahwa seorang anak jika dihadapkan pada suatu masalah maka mereka bukan hanya sekedar memecahkan masalah tersebut tetapi juga belajar sesuatu yang baru dan mendapat pengetahuan yang baru pula. Sehingga problem solving atau pemecahan masalah bertujuan agar anak bukan hanya mengetahui tetapi memahami konsep kehidupan dengan pemecahan masalah sehingga dapat berpikir logis, kritis serta sistematis.

\section{METODE}

Metode penelitian yang digunakan adalah penelitian studi literatur. Artikel ini berisi tentang kajian literatur tentang Pentingnya melatih problem solving pada anak usia dini dimana sistem pengambilan data bersumber dari buku-buku serta jurnal-jurnal yang dianalisis berdasarkan permasalahan yang samaserta sumber-sumber terkait yang mengarah pada judul penelitian ini. Mardalis (1999) Studi literatur merupakan suatu studi yang digunakan dalam mengeumpulkan informasi serta data dengan bantuan berbagai macam sumber perpustakaan seperti dokumen, buku, majalah, kisah-kisah sejarah, dan lain sebagainya. sejalan dengan itu Nazir (2014) berpendapat bahawa studi literatur adalah teknik pengumpulan data dengan menelaah buku-buku, literature-literatur, catatan-catatan serta laporan-laporan yang berhuungan dengan masalah yang ingin dipecahkan.

\section{HASIL DAN PEMBAHASAN \\ Problem solving}

problem solving berasal dari John

Dewey. Metode problem solving memiliki maksud untuk memberikan latihan kepada anak agar anak berpikir dalam menyelesaikan suatu masalah dengan tepat, kritis serta sistematis sehingga dengan metode ini anak akan belajar untuk berpikir tenang dan tidak tergesa-gesa dalam menyimpulkan suatu masalah. Matthews (dalam utami, 20170 mengemukakan bahwa kontruktivisme merupakan suatu teori filsafat pengetahuan yang menekankan bahwa pengetahuan yang kita miliki merupakan hasil dari pembentukan yang berasaldari diri kita sendiri.

\section{Kemampuan Problem solving untuk Anak Usia Dini}

Kemampuan problem solving perlu dikembangkan sejak usia dini karena hakikatnya anak adalah individu yang tertarik dan penasaran terhadap lingkungan sekittarnya sehingga dengan mengembangkan kemampuan problem solving akan meningkatkan kognitif anak. Seperti yang dikemukakan oleh Beaty (1994) \& Wortham (2006) (dalam Syaodih, 2018) mengemukakan bahwa dengan pemecahan masalah atau problem solving pada anak usia dini akan membuat anak mampu serta menambah pengelaman dalam merumuskan hipotesis, pengumpulan data atau informasi, serta menarik kesimpulan dengan proses ilmiah. Sejalan dengan itu Brewer \& Scully (dalam Syaodih, 2018) mengemukakan pemecahan masalah atau problem solving pada anak usia dini meliputi keterampilan, observasi, membandingkan, mengukur, menghubungkan, mengkomunikasikan, eksperimen serta menyimpulkan dan menggunaakan informasi. Selain itu branca (dalam syaodih, 2018) juga menyatakan bahwa pemecahan masalah juga merupakan suatu proses atau langkah-lagkah untuk mengatasi suatu permasalahan dengan pemecahan masalah dengan melakukan suatu kegiatan dalam menerapkan konsep-konsep serta aturan 
dalam menyelesaikan masalah tersebut. dengan problem solving maka anak akan memperoleh pengalaman belajar yang bermakna dimana anak akan mencoba, menemukan serta melakukan interaksi sosial dalam menyelesaikan masalah.

Maria (dalam Syaodih, 2018) mengemukakan indikator keterampilan problem solving pada anak usia dini antara lain: 1) keterampilan observasi atau mengamati, 2) mengumpulkan data dan informasi, 3) mengolah informasi, dan 4) mengkomunikasikan informasi. Untuk meningkatkan jiwa problem solving pada anak maka guru atau pendidik juga memiliki peran yang sangat penting dimana guru dapat mengungkapkan suatu masalah dan menghadapkan anak pada masalah tersebut serta mendiskusikan pemecahan masalah sehingga anak anak berpikir untuk memecahkan masalah tersebut dengan melalui proses ilmiah. Syaodih (2018) mengemukakan ciri-ciri model pembelajaran dalam problem solving yaitu : 1) menggajukan pertanyaan atai permasalahan, 2) berfokus pada keterkaitan antar masalah, 3) penyelidikan secara autentik, dan 4) memecahkan masalah atau menghasilkan/menciptakan produk.

\section{Problem solving yang dilakukan melalui bermain}

Piaget (dalam Bobik, 2006) mengemukakan bermain merupakan wahana yang dapat mengembangkan anak dalam berpikir. Bermain juga merupakan cara belajar yang sangat efektif diterapkan kepada anak karena pada hakikatnya anak belajar dengan bermain, belajar seraya bermain. Sejalan dengan itu Froebel dalam Audrey Curtis (dalam Bobik, 2006) menyakan bahwa dengan bermain maka kreatifitas anak akan berkembang, selain itu anak akan bereksplorasi dengan berbagai objek karena hal tersebut maka pengetahuan serta pemahaman anak akan semakin berkembang tentang segala hal. Banyak contoh kegiatan atau permainan yang dapat dilakukan oleh guru, orang tua serta masyarakat dilingkungan sekitar untuk mengajarkan kemandirian, kreatif, serta memiliki kecakapan dalam memecahkan suatu masalah atau problem solving yaitu dengan bermain puzzle, bermain muze, bongkar pasang.

\section{Bermain Puzzle}

Soebachman (2012) mengemukakan bermain Puzzle merupakan permainan yang terdiri atas suatu kepingan-kepingan gambar untuk disusun yang dapat melatih konsentrasi pada anak. Sejaland engan itu yuliani (2008) mengemukakan bermain puzzle sangat bermanfaat dalam mengasah otak anak dimana anak akan mencari, menemukan menyusun, mencocokkan, serta melatih kesabaran untuk menyelesaikan susunan fiuzzle.

Aktivitas bermain puzzle merupakan bentuk pemberian simulasi dalam proses pembelajaran dimana dengan bermain puzzle akan membangun pengetahuan dengan mengaitkan pengetahuan terdahulu dengan pengetahuan baru dan memperluas pengetahuan anak serta cara berpikir anak dalam menyelesaikan sebuat teka-teki atau permasalahan dengan kritis serta sistematis.

\section{Mate}

Mate mrupakan sebuah permainan yang dapat meningkatkan cara berpikir anak dalam menyelesaikan sebuah permasalahan atau biasa disebut problem solving dimana dalam permainan ini akan menggunakan jalur berliku dan sepit. Permainan mate biasanya dibuat dari kertas karton serta membuat beberapa perintah seperti menuju jalan ke rumah atau sebuah tempat, mencocokan benda seperti mencocokkan hewan dengan makanannya, mencocokkan orang dengan tempat ibadahnya dan lain sebagainya. Permainan ini juga tidak memerlukan media ataupun alat yang sulit didapat seperti permainan ini hanya membutuhkan kertas serta pensil jadi tidak ada halangan atau terkendala tentang bahan dan alat jika orang tua membuat permainan maze dirumah karena permainan ini sangat efektif untuk mengembangkan problem solving pada anak atau dapat dikatakan anak akan belajar menyelesaikan masalah dengan berpikir atau melalui sudut pandangnya.

\section{Bongkar Pasang}

Permainan bongkar pasang tidak jauh beda dengan permainan puzzle dimana permanan bongkar pasang yaitu membongkar 
dan memasang suatu benda sehingga menjadi bentuk yang diharapkan. Ismail (dalam hasnawati, 2016) mengemukakan permainan bongkar pasang merupakan permainan yang menyusun suatu gambar dimana gambar dipecah-pecah menjadi beberapa bagian serta permainan bongkar pasang ini dapat melatih kecerdasan anak karena harus berpikir untuk mencocokkan bentuk yang satu ke bentuk yang lainnya agar terlihat gambar seperti yang diharapkan. Kegiatan bongkar pasang sangat cocok digunakan kepada anak usia dini karena dengan permainan tersebut anak akan dilatih berpikir dan permainan tersebut juga menyenangkan serta tidak memerlukan bahan dan alat yang rumit. Muzamil (dalam Hasnawati, 2016) mengemukakan bahwa permainan bongkar pasang memiliki beberapa jenis, diantaranya yaitu bongkar pasang konstruksi, bongkar pasang matang, bongkar pasang lantai, bongkar pasang huruf, bongkar pasang hijaiyah, bongkar pasang bentuk buah, bongkar pasang bentuk hewan, bongkar pasang bentuk transportasi, bongkar pasang tentang logika, bongkar pasang blok, dan lain sebagainya.

\section{KESIMPULAN}

Metode problem solving merupakan salah satu metode yang sangat bagus di terapkan kepada anak usia dini karena dengan metode tersebut anak dituntut berpikir untuk menyelesaikan sebuah masalah atau menciptakan sesuatu dengan melewati prosesproses yang memberi anak pengalaman belajar bukan hanya mendapatkan hasil tanpa belajar. Metode problem solving bukan hanya memberikan anak peluang untuk belajar ketika menyelesaikan sesuatu tetapi memberikan anak pengalaman bahwa ketika ingin menarik kesimpulan mesti mempertimbangkan terlebih dahulu atau dapat dikatakan tidak tergesa-gesa, serta membuat anak berpikir secara sistematis, logis dan kritis. Dengan metode problem solving kemampuan intelektual anak akan berkembang dengan baik dan kemampuan intelektual akan bersifat kompleks dengan metode problem solving karena dengan metode ini anak akan memiliki kemampuan tentang konsep-konsep, kaidah-kaidah sehingga dapat menerapkan konsep serta kaidah tersebut dalam memecahkan masalah didalam kehidupan sehari-hari. Hal tersebut dapat diketahui bahwa kemampuan pemecahan masalah atau problem solving anak usia dini menggunakan kemampuan terhadap pengalamannya dalam merumuskan hipotesis, mengumpulkan data serta menarik kesimpulan atau keputusan. Anak yang dapat menyelesaikan masalah sendiri menunjukkan bahwa kognitif serta cara anak berpikir memiliki kemajuan sehingga anak akan berkembang dengan baik. Dalam menyelesaikan masalah atau problem solving sebaiknya dengan bermain karena pada hakikatnya dunia anak yaitu dunia bermain jadi lakukanlah sebuah kegiatan yang menyenangkan untuk segala hal bagi anak tentunya hal tersebut berlaku dalam mnyelesaikan masalah juga. Melalui bermain kemampuan dan potensi anak akan berkembang dengan optimal, adapun permainan yang dapat mngembangkan jiwa problem solving pada anak yaitu dengan permainan puzzle, maza, bongkar pasang dan sebagainya.

\section{REFERENSI}

Bobik, P., Boschini, M. J., Gervasi, M., Grandi, D., Kudela, K., \& Rancoita, P. G. (2006). Primary helium or inside the magnetosphere: A transmission function study.

Hasnawati, Ahmad, A., \& Afendi, J. (2016). Implementasi permainan bongkar pasang dalam melejitkan berbagai aspek perkembangan anak usia dini pada Paud It Ar-Rahmah Banda Aceh. Jurnal Ilmiah Mahasiswa Pendidikan Anak Usia Dini, 1(1), 19-28.

Pendidikan, K., \& Kebudayaan, D. A. N. (2015). Menteri pendidikan dan kebudayaan republik indonesia nomor 137 Tahun 2013

Syaodih, E., Setiasih, O., Romadona, N. U. R. F., \& Handayani, H. (2018). Pengembangan kemampuan pemecahan masalah anak usia dini dalam pembelajaran proyek di taman kanak-kanak. Jurnal Pendidikan Anak, 12(1), 29-36. 
Utami, L. O., Utami, I. S., \& Sarumpaet, N. (2017). Penerapan metode problem solving dalam mengembangkan kemampuan kognitif anak usia dini melalui kegiatan bermain. Tunas Siliwangi, 3(2), 175-180.
Wilson, J. L., \& Wilson, J. L. (2019). Approaches to learning. In student learning in higher education. https://doi.org/10.4324/978042944 5569-7 